\section{Ei juuri uutta tasa-arvosta}

Ohisalo, Maria \& Kotro, Arno (toim.) (2019). Sinua on petetty.

Kirjoituksia sukupuolten tasa-arvosta. Like. 204 sivua.

SINUA ON PETETTY -esseekokoelmassa kymmenen yhteiskunnallista keskustelijaa kirjoittaa sukupuolten tasa-arvosta. Kirjoittajat ovat eri aloilta, mutta yhteistä heille on tunnettuus. Mukana on muun muassa tutkijoita, taiteilijoita, journalisteja ja kirjoittamisen ammattilaisia.

Esseet liikkuvat eri aihepiireissä. Niissä käsitellään muun muassa feminististä huumoria, kiltin tytön syndroomaa ja kapeaa käsitystä maskuliinisuudesta.

Teoksen lähtökohtia kuvataan johdannossa. Köyhyystutkija Maria Ohisalo oli laatinut blogitekstin, jossa hän totesi, ettei "tasa-arvo ole valmis". Kirjailija-opettaja Arno Kotro kommentoi tekstiä, ja viestinvaihto johti heidät yhteisiin teehetkiin ja keskusteluihin.

Tasa-arvokysymyksiin perehtynyt lukija voi päätellä jo johdannon alkuosan luettuaan, ettei teos tarjoa erityisen ravistelevia havaintoja sukupuolten epätasa-arvosta. Kirjoitukset ovat kuitenkin tärkeitä puheenvuoroja, ja erityisen ansiokasta on, että kirjoittajat eivät sorru kapulakielisyyksiin. Mukana on myös esseitä, jotka käsittelevät vähälle huomiolle jääneitä aiheita, kuten vammaisten naisten naiseuden ilmaisua.

\section{KAPEAT LOKEROT}

Kirjan avaa sateenkaariperheitä tutkinut Anna Moring esseellään, joka antaa lukijalle eväitä sukupuolten moninaisuuden ymmärtämiseen. Kaksinapaista sukupuolijaottelua kritisoituaan Moring kuvaa napakalla otteella, miten tytöistä tuotetaan tyttöjä ja pojista poikia. Hän osoittaa, kuinka tiukassa näkemyksemme sukupuoliin liitetyistä piirteistä istuvat. Uskomme sinnikkäästi, että pojat ovat kykenemättömiä kantamaan vastuuta teoistaan, joten tyttöjen täytyy kiiruhtaa apuun. Lapsuudessa omaksutut käsitykset siirtyvät aikuisuuteen, ja toistammekin "miehet ovat Marsista ja naiset Venuksesta" -lausahduksia.

Juho Pylvänäinen ja Arno Kotro kirjoittavat hekin omissa esseissään kapeista sukupuolilokeroista, joihin yksilöiden oletetaan mukautuvan. Feministisen miesjärjestön Miehet ry:n perustajiin kuuluva Pylvänäinen muistelee kouluaikojaan ja palaa kiusaamiskokemuksiinsa. Jouhevasti etenevä essee pohtii maskuliinisuutta ja miessukupuolen tuottamista.

Kokoelman räväkimmässä esseessä Kotron ruotii "vinoa tasa-arvodiskurssia”. Hän muistelee, kuinka 1990-luvun alussa käytiin "ällistyttävää keskustelua" miesten asevelvollisuudesta tasaarvokysymyksenä. Keskustelun seuraaminen sai Kotron kiinnittämään huomiota muunkin tasa-arvokeskustelun yksipuolisuuteen: keskusteluissa demonisoitiin ja

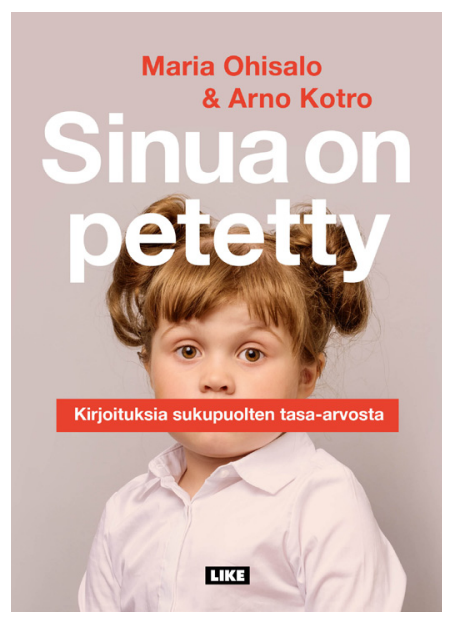

vähäteltiin miessukupuolta. Kotron mukaan miehen on edelleen helppoa erottua edukseen, verrataanhan häntä myyttiseen turjakemieheen, jolla ei ole tunnetaitoja eikä kykyä sanalliseen ilmaisuun. Naisilla sitä vastoin on suuret paineet, sillä naissukupuolen ylivertaisuutta on todisteltu väsymättömästi.

\section{KUINKA TASA-ARVOINEN SUOMI ON?}

Poliitikko ja apulaispormestari $\mathrm{Na}$ sima Razmyarin mukaan tuudittaudumme Suomessa ajatukseen, että meillä on asiat hyvin tasa-arvon suhteen. Tällöin on helppoa lausahtaa, tarvitseeko tasa-arvosta enää edes puhua. Razmyar painottaa esimerkin antamisen tärkeyttä. Hän toteaa, että poliittisilla toimijoilla on vaikutus siihen, mitä arvoja tuodaan esille päätöksenteossa. Samoin yritykset voivat pitää kiinni tärkeiksi kokemistaan arvoista ja esimerkiksi noudattaa nollatoleranssia seksuaalisessa 


\section{USKOMME, ETTÄ POJAT OVAT KYKENEMÄTTÖMIÄ}

KANTAMAAN VASTUUTA TEOISTAAN.

häirinnässä. Razmyarin essee on maltillinen puheenvuoro, josta jää puuttumaan terävin kärki.

Journalisti Maria Pettersson tarttuu samoihin teemoihin rohkeammalla otteella. Hän rökittää kiintiöajattelua, mutta toteaa itsekin, että kiintiöitä vielä tarvitaan valitettavasti. Petterssonin tekstiä on miellyttävää lukea, ja hän ujuttaa onnistuneesti mukaan huumoria. Tiesitkö, että suomalaisia pörssiyhtiöitä johtavat useammin Juha-nimiset miehet kuin naiset?

Vielä vähemmän valtakunnan kärkipaikoilla on nähty vammaisia, kansanedustajinakin vain yksi, Kalle Könkkölä. Vammaisten kohtaaman sorron arkipäiväisyydestä huolimatta vammaisuus on teema, joka usein edelleen unohtuu tasa-arvokeskusteluissa.

Esseekokoelmassa vammaisten äänen tuo kuuluville taiteilija Jenni-Juulia Wallinheimo-Heimonen, jonka essee on pamfletin onnistunein ja tärkein teksti. Hän pohtii muun muassa vammaisten naisten voimautumista "Olemme naisia, emme vain vammaisia" -liikehdinnässä. Kun tilaisuuksiin kutsuttiin pukeutumisneuvojia ynnä muita opastajia, naiset päätyivät väittelemään, pitäisikö "proteesi piilottaa vai tuunata tyrmäävän upeaksi”. Teksti herättää kaltaisessani vammattomassa lukijassa halun päästä keskustelemaan lisää naiseuden, vammaisuuden ja kauneusihanteiden risteämisistä.

\section{KOHTI VAIKUTTAVAA}

\section{FEMINISTISTÄ VIESTINTÄÄ}

Katleena Kortesuon, Saara Särmän ja Koko Hubaran esseitä yhdistää viestintä. Viestinnän asiantuntija Kortesuo johdattaa lukijan sosiaalisen median aikakauteen ja väittää, että jokainen työ on nykyään julkista. Hän lupaa antaa neuvoja, miten feministin kannattaa toimia mediassa. Tekstistä jää kuitenkin hieman sekava vaikutelma, eivätkä esimerkitkään aina selkeytä sanomaa.

Tutkija Särmä kirjoittaa huumorista. Hän väittää, etteivät vakavuus ja hauskuus sulje välttämättä toisiaan pois, ja nauru voi olla voimakas poliittinen teko, mistä Maria Petterssonin essee on oiva esimerkki. Karnevalisointi paljastaa sukupuolinormien järjettömyyden. Kuten Särmä muistuttaa, ensin normi täytyy havaita, vasta sitten voidaan käydä purkutöihin.

Toimittaja Hubara kertaa Ruskeat tytöt-blogin tarinan ja kuvailee samalla nousuaan julkisuuteen ja siirtymistään kirjallisuuden kentälle. Ei liene yllätys, että hän huomasi senkin olevan valkoinen. Hubaran mukaan siellä "pätevät samat lainalaisuudet kuin journalismissakin" eli valkoisen cis-heteromiehen ääni on kuuluvin.

\section{KIRJOITTAMISEN \\ AMMATTILAISTEN TAITO NÄKYY}

Esseekokoelma on hyvä johdatus sukupuolten tasa-arvoa koskeviin pohdintoihin, mutta aiheeseen syvemmin perehtyneille se ei anna paljonkaan uutta. Aiheesta kiinnostunut lukija saa kuitenkin mahdollisuuden peilata esseissä esitettyjä havaintoja omaan arkeensa. Koska monet kirjoittajat ovat viestinnän moniosaajia, kieli on elävää ja monin paikoin sopivan rentoa.

Tasa-arvokysymyksiin pureutuvan esseekokoelman saattaisi kuvitella sisältävän runsaasti vaikeita termejä ja käsitteitä. Huoli on onneksi aiheeton: 'intersektionaalisuus', 'herruustekniikat', 'poc-ihmiset' - kaikki termit selostetaan selväsanaisesti.

Loppusanoissa Maria Ohisalo ja Arno Kotro toivovat antaneensa sytykkeitä tasa-arvokeskusteluun. Kokonaisuutena kokoelma jää kuitenkin melko laimeaksi. Mukaan olisi voinut ottaa rohkeampiakin puheenvuoroja. Ilahduttavaa on näkymien avaaminen harvemmin käsiteltyihin teemoihin, kuten kirjallisuuden tasa-arvokysymyksiin.

\section{ERJA LAAKKONEN}

KT, FM, yliopistonlehtori Itä-Suomen yliopisto 